\title{
KEMAMPUAN BAKTERI ENDOFIT TANAMAN SEMANGKA DALAM MENEKAN PERKEMBANGAN PENYAKIT BERCAK DAUN YANG DISEBABKAN OLEH JAMUR COLLETOTRICHUM SP.
}

\author{
Eryna Elfasari Rangkuti, Dwi Suryanto, Kiki Nurtjahja, \& Erman Munir
}

Departemen Biologi, Fakultas Matematika dan Ilmu Pengetahuan Alam, Universitas Sumatera Utara, Jl. Bioteknologi No.1, Kampus USU, Medan, Indonesia 20155,

E-mail: dwisuryanto@usu.ac.id

\begin{abstract}
Ability of watermelon endophytic bacteria to suppress development of leaf spot disease caused by Colletotrichum sp. A studi on assay of endophytic bacteria to control Colletotrichum sp., causal agent of leaf spot disease on watermelon, was conducted. Colletotrichum sp. was isolated from infected leaf of leaf spot disease, while endophytic bacteria were isolated from stem, leaf, and root of watermelon healthy plant. Antagonistic assay was conducted by dual culture method. Hyphal abnormalities as a result of antagonistic assay was observed using light microscope. To determine the ability of endophytic bacterial isolates to control leaf spot disease, watermelon seeds were treated by dipping the seed in endophytic bacterial suspension. Seven endophytic bacterial isolates showed to inhibit Colletotrichum sp. to some extent. Two isolates DS 01 and BS 01 showed relatively high inhibition zone compared to others, therefore were choosen for further study. Abnormal hyphae such as broken, lysis, twisted, curled, and swollen hyphae were recorded as the result of antagonistic assay. Watermelon seed treatment revealed that dipping the seed in endophytic bacterial suspension of DS 01 and BS 01 reduced leaf spot disease to 12 and $24 \%$, but inhibited seed growth by $12 \%$ and $44 \%$, respectively. It seemed that all treatments showed to reduce seedling performance i.e seedling height, leaf number, and dry weight, compared to that of (-) control. DS 01 however seemed to increase dry weight of watermelon plants.
\end{abstract}

Key words: Colletotrichum sp., endophytic bacteria, leaf spot disease, watermelon

\begin{abstract}
ABSTRAK
Kemampuan bakteri endofit tanaman semangka dalam menekan perkembangan penyakit bercak daun yang disebabkan oleh jamur colletotrichum $s$. Penelitian tentang pengujian bakteri endofit dalam menghambat Colletotrichum sp. agen penyebab penyakit bercak daun pada tanaman semangka telah dilakukan. Colletotrichum sp. diisolasi dari daun yang terkena bercak daun, sedangkan bakteri endofit diisolasi dari batang, daun, dan akar tanaman semangka yang sehat. Uji antagonis dilakukan dengan metode kultur ganda dua. Abnormalitas hifa sebagai akibat dari uji antagonis diamati di bawah mikroskop cahaya. Untuk mengetahui kemampuan isolat endofit dalam mengendalikan penyakit bercak daun, benih semangka diperlakukan dengan cara merendam dalam suspensi bakteri endofit. Tujuh isolat bakteri endofit terlihat menghambat Colletotrichum sp. dengan kemampuan yang berbeda. Dua isolat DS 01 dan BS 01 menunjukkan zona hambat yang lebih besar dibandingkan dengan isolat lainnya, oleh karena itu dipilih untuk telaah lanjutan. Hifa abnormal seperti hifa patah, lisis, menggulung, keriting, dan bengkak terlihat sebagai akibat dari uji antagonis. Perlakukan benih semangka dengan cara perendaman dalam suspensi isolat DS 01 dan BS 01 menurunkan serangan penyakit bercak daun menjadi 12\% dan 24\%, namun menyebabkan 12\% and $44 \%$ benih tidak tumbuh. Kelihatannya semua perlakuan menyebabkan penurunan performa tanaman seperti tinggi kecambah, jumlah daun, dan berat kering dibandingkan dengan kontrol (-), kecuali DS 01 yang terlihat meningkatkan berat kering
\end{abstract}

Kata kunci: bakteri endofit, bercak daun, Colletotrichum sp., semangka

\section{PENDAHULUAN}

Semangka merupakan salah satu buah yang digemari. Seperti tanaman buah lain, semangka juga merupakan salah satu buah yang rentan terhadap serangan hama serta patogen tanaman. Permasalahan hama dan penyakit tanaman, khususnya jamur patogen sangat perlu untuk diwaspadai, karena selain mengganggu pertumbuhan juga dapat mengakibatkan penurunkan produksi semangka. Salah satu jamur patogen yang sering menyerang tanaman semangka adalah jamur Colletotrichum sp., penyebab penyakit bercak daun. 
Dalam mengendalikan penyakit tanaman yang disebabkan oleh jamur, fungisida sintetis masih sering digunakan sebagai pilihan utama. Namun begitu, banyak laporan yang menyebutkan bahwa penggunaan fungisida memberikan dampak negatif antara lain pencemaran lingkungan, dan menyebabkan resistensi patogen tanaman (Anitha \& Rabeeth, 2009). Oleh karena itu perlu terus dicari dan dikembangkan alternatif pengendalian yang ramah lingkungan melalui pengendalian hayati.

Penelitian-penelitian untuk melihat kemampuan bakteri endofit sebagai pengendali hayati dalam sistem pertanian organik dan berkelanjutan saat ini sudah banyak dilakukan (Haggag, 2010). Beberapa penelitian telah menunjukkan kemampuan bakteri endofit tanaman untuk melindungi tanaman dari serangan penyakit dan memperbaiki performa tanaman (Haggag, 2010; Attia et al., 2011). Potensi penggunaan bakteri endofit berhubungan dengan kemampuan bakteri tersebut untuk menghasilkan berbagai hormon pertumbuhan dan menginduksi protein antifungi seperti chitinase dan $\beta$-1,3-glukanase, peroksidase, fenilalanin ammonia-liase, fenolat, dan polifenol oksidase (Ramamoorthy et al., 2002; Attia et al., 2011; Govindappa et al., 2011). Ziedan (2006) dan Haggag (2010) melaporkan bahwa kemampuan kolonisasi bakteri endofit asal tanaman yang sama merupakan salah satu cara bakteri endofit untuk meningkatkan performa tanaman.

Melihat kemampuan bakteri endofit dari hasil penelitian sebelumnya, dilakukan isolasi dan seleksi bakteri endofit dari tanaman semangka yang berpotensi untuk digunakan sebagai agensia hayati pengendali jamur Colletotrichum sp. penyebab penyakit bercak daun. Sejauh ini penelitian tentang pemanfaatan isolat bakteri endofit pada tanaman semangka di Indonesia untuk mengendalikan serangan penyakit bercak daun belum pernah dilakukan.

\section{METODE PENELITIAN}

Tempat dan Waktu. Penelitian ini di laksanakan di Laboratorium Mikrobiologi, Departemen Biologi, Fakultas Matematika dan Ilmu Pengetahuan Alam, Universitas Sumatera Utara, Medan. Waktu pelaksaan penelitian ini pada bulan April sampai September 2013.

Isolasi Colletotrichum sp. dari Daun Semangka Sakit. Isolat jamur patogen berasal dari daun semangka yang terkena penyakit bercak daun. Bahan tanaman yang terserang penyakit dipotong menjadi 4 bagian. Bagian tanaman tersebut diletakkan pada permukaan media potato dextrose agar (PDA) yang telah dicampurkan dengan antibiotik kloramfenikol ( 0,3 gram/ $100 \mathrm{ml}$ ) dengan posisi bekas potongan ke arah media. Kultur diinkubasi pada suhu ambien selama 2 hari. Koloni yang muncul dari sebelah dalam disubkulturkan ke media PDA yang baru sampai didapat biakan murni. Pengamatan hifa dan spora dilakukan dengan menggunakan mikroskop. Identifikasi dilakukan dengan membandingkan morfologi koloni, hifa, dan spora menggunakan buku Alexopoulos \& Mims (1979).

Isolasi Bakteri Endofit dari Tanaman Semangka Sehat. Contoh akar, batang, dan daun semangka dari kebun semangka di Kecamatan Batang Kuis, Deli Serdang, Sumatera Utara diisolasi seperti metode Radu \& Kqueen (2002). Penyiapan potongan contoh seperti yang dilakukan di sebelumnya. Contoh akar, batang dan daun dicuci bersih, direndam dalam larutan etanol $75 \%$ selama 2 menit, larutan natrium hipoklorit 5,3\% selama 5 menit, dan etanol $75 \%$ selama 30 detik, kemudian ditanam pada media agar nutrien, kemudian dilakukan teknik biakan murni sampai memperoleh isolat bakteri.

Uji Antagonis Bakteri Endofit Semangka terhadap Colletotrichum sp. Uji antagonisme in vitro dalam cawan Petri menggunakan metode kultur ganda dengan difusi cakram. Biakan jamur ditumbuhkan di tengah media PDA + 3\% ekstrak khamir dengan jarak 3,5 cm dari tempat inokulum bakteri. Biakan diinkubasi selama 48 jam pada suhu ambien.

Koloni bakteri endofit diambil secukupnya dengan menggunakan jarum ose, lalu dimasukkan ke dalam tabung reaksi yang berisi $10 \mathrm{ml}$ larutan $\mathrm{NaCl}$ kemudian diukur absorbansinya untuk mendapatkan $\mathrm{OD}_{600}=0,5$ $\left(\approx 0^{8} \mathrm{CFU} / \mathrm{ml}\right.$ ). Kertas cakram (Oxoid) direndam dalam suspensi bakteri dan diinokulasikan pada sisi berdampingan dengan jamur dengan jarak $3 \mathrm{~cm}$ dari koloni jamur. Pengamatan dilakukan dari hari ke-2 sampai hari ke-7 dengan melihat zona hambat terbesar. Aktivitas penghambatan ditentukan berdasarkan zona hambat terbesar yang terbentuk di sekitar koloni bakteri. Zona hambat diukur sebagai diameter koloni jamur patogen normal dikurang diameter jamur patogen yang terhambat dibagi dua.

Pengamatan Struktur Hifa Colletotrichum sp. setelah Uji Antagonis. Pengamatan struktur hifa dengan cara mengamati ujung miselium pada daerah zona hambat jamur patogen menggunakan mikroskop dengan perbesaran 10 x 10 kali. Ujung miselium Colletotrichum sp., yang tumbuh pada permukaan media dipotong dengan bentuk block square, kemudian diletakkan pada gelas objek. Miselium abnormal ditandai 
dengan ujung miselium membengkok, miselium keriting, miselium bengkak, miselium bercabang, miselium lisis, dan miselium tumbuh kerdil.

\section{Uji Potensi Penghambatan Bakteri Endofit terhadap Perkembangan Penyakit Bercak Daun} pada Benih Semangka. Dua isolat bakteri yaitu DS 01 dan BS 01 dipilih untuk uji lanjut berdasarkan kemampuan terbesar dalam menghambat pertumbuhan hifa jamur. Sebanyak $120 \mathrm{ml}$ suspensi konidia Colletotrichum sp. $\left(\approx 10^{7}\right.$ konidia/ml $)$ dicampurkan dengan $500 \mathrm{~g}$ campuran tanah dan kompos steril (nisbah 3:1) sebagai media tumbuh dalam polybag.

Sebanyak 5 benih semangka yang telah direndam dengan suspensi bakteri endofit $\left(\mathrm{OD}_{600}=0,5\right)$ masingmasing ditanam dalam media tumbuh yang telah diberi konidia. Benih yang direndam selama 30 menit pada akuades steril yang tidak diinokulasi bakteri endofit dan tidak ditanam pada media tanpa pemberian konidia digunakan sebagai kontrol (+), sedang benih yang ditanam pada media dengan pemberian konidia digunakan sebagai kontrol (+). Uji juga dilakukan untuk mengetahui patogenisitas bakteri terhadap benih semangka dengan hanya memberikan isolat bakteri pada benih tanpa pemberian konidia. Tanaman yang terserang bercak daun, tinggi tanaman, dan jumlah daun, dan berat kering selama persemaian 30 hari diamati dan dicatat.

Persentase tanaman yang terserang bercak daun dihitung sebagai (jumlah tanaman yang terserang/jumlah tanaman) x $100 \%$. Pengukuran tinggi kecambah dilakukan dengan mengukur mulai dari batas terbawah bagian batang yang tepat pada permukaan tanah sampai batas teratas di ujung daun yang diluruskan ke atas sejajar batang dengan menggunakan benang wol mengikuti lekukan batang. Pengukuran berat kering kecambah dilakukan pada akhir pengamatan melalui penimbangan kecambah yang sudah dikeringkan dengan oven pada suhu $105^{\circ} \mathrm{C}$ selama 1-3 hari sampai diperoleh berat kering yang konstan.

\section{HASIL DAN PEMBAHASAN}

Isolasi Colletotrichum sp. dan Bakteri Endofit dari Tanaman Semangka. Berdasarkan pengamatan makroskopis dan mikroskopis isolat jamur yang didapat memiliki karakteristik makroskopis berupa koloni berwarna putih, permukaan koloni seperti beludru atau kapas, miselium teratur, pertumbuhan koloni rata dan tebal sementara tepi koloni rata dan berwarna putih. Karakteristik mikroskopisnya berupa hifa tidak bersekat, konidia tunggal atau lebih yang terdapat pada ujung hifa, bagian sel konidia kedua lebih besar dan berwarna gelap daripada bagian sel yang lainnya, konidiofornya berwarna coklat muda dan tidak bercabang sesuai dengan karakteristik Colletotrichum sp. (Gambar 1).

Isolat bakteri endofit berasal dari kajian sebelumnya (data tidak dipublikasi), yang memiliki karakterisasi yang bervariasi baik dalam morfologi maupun sifat pewarnaan. Tepi koloni isolat didominasi oleh gelombang, bentuk koloni isolat didominasi oleh tidak beraturan, elevasi koloni memiliki tipe datar pada seluruh koloni isolat, warna koloni isolat didominasi oleh warna kuning. Pada pewarnaan gram bakteri diperoleh 5 isolat gram positif dan 2 isolat gram negatif, sedangkan penataan sel bakteri diperoleh 3 isolat batang dan 4 isolat berbentuk bulat.

Uji Antagonis Bakteri Endofit Semangka Terhadap Colletotrichum sp. Hasil uji antagonis tujuh isolat bakteri hasil isolasi sebelumnya, yaitu isolat DS 01, BS 01, AS 01, AS 02, DS 02, DS 03 dan DS 04 terhadap

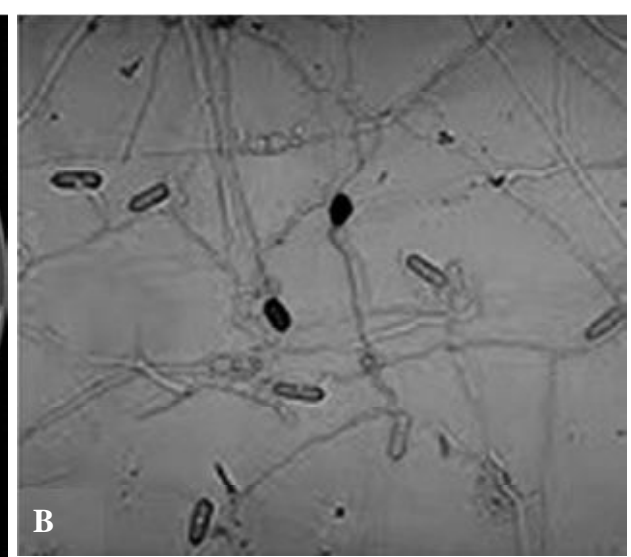

Gambar 1. (A) Koloni Colletotrichum sp. pada media PDA, dan (B) Hifa dan konidia Colletotrichum sp. 
Colletotrichum sp. menunjukkan bahwa tujuh isolat bakteri tersebut mampu menghambat pertumbuhan Colletotrichum sp. Hal ini dapat dilihat dari terbentuknya zona hambat pada pertumbuhan Colletotrichum sp. oleh bakteri endofit seperti pada Gambar 2. Zona hambat mulai terlihat pada hari keempat dan jarak zona hambat terus bertambah hingga hari ketujuh.
Pada hari ke-7, isolat bakteri endofit yang memperlihatkan efektifitas paling tinggi dalam menghambat pertumbuhan Colletotrichum sp. adalah DS 01 dengan zona hambat 18,5 mm dan BS 01 dengan zona hambat $15,5 \mathrm{~mm}$. Isolat bakteri endofit yang memperlihatkan aktivitas penghambatan paling rendah adalah isolat DS 04 dengan zona hambat $10 \mathrm{~mm}$ yang dapat dilihat pada Gambar 3.
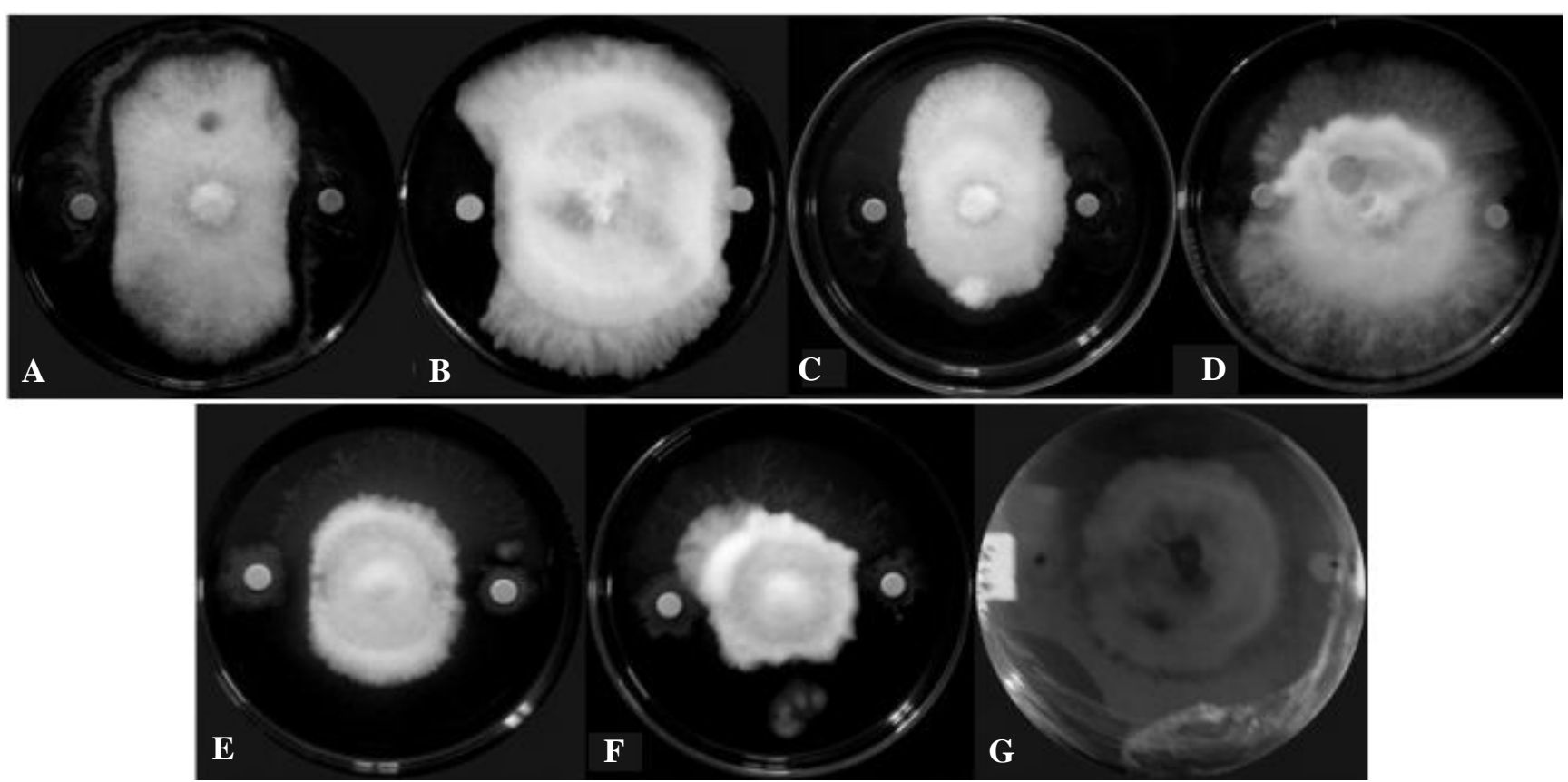

Gambar 2. Hasil uji antagonis in vitro Colletotrichum sp. dengan isolat bakteri endofit pada hari ketujuh: (A)

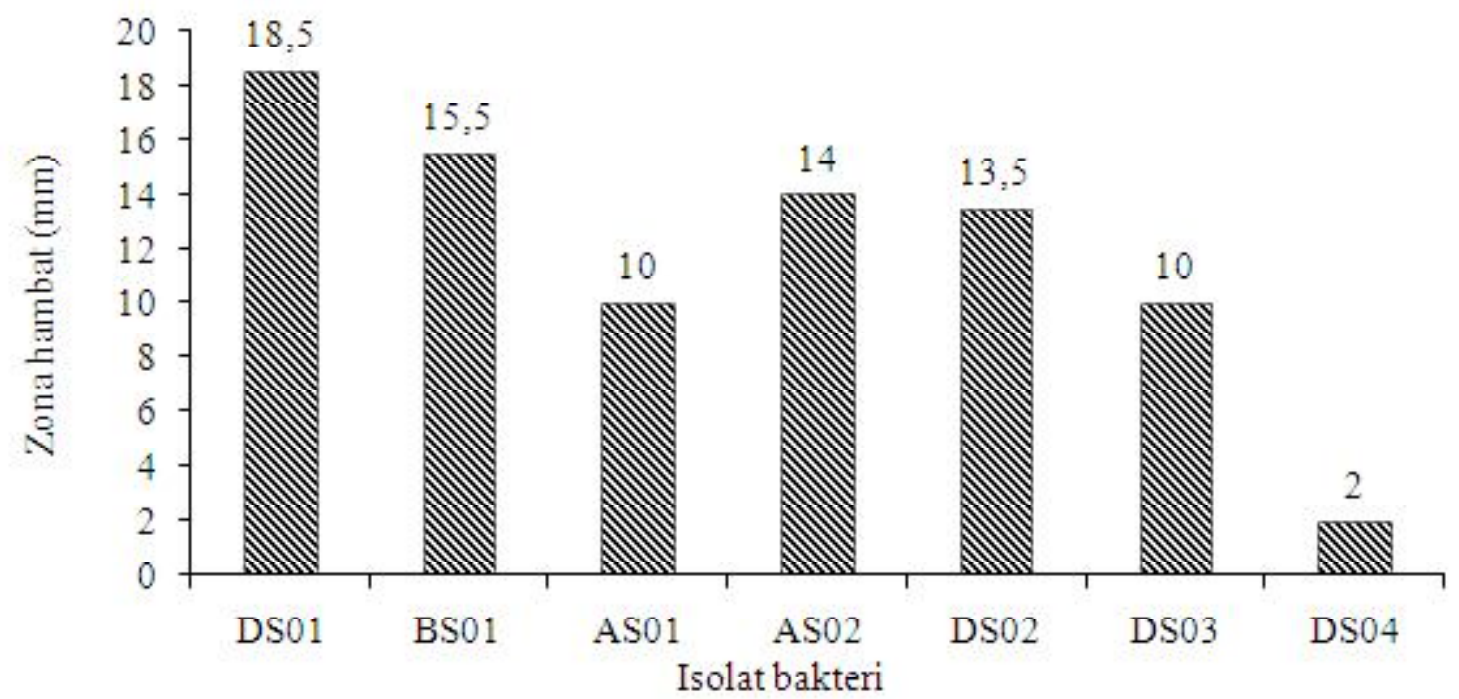

Gambar 3. Hasil uji antagonis in vitro antara tujuh isolat bakteri endofit terhadap Colletotrichum sp. 
Perbedaan efektivitas penghambatan pertumbuhan jamur disebabkan oleh adanya perbedaan komposisi dinding sel jamur, keberadaan kitin pada miselium jamur, perbedaan laju pertumbuhan bakteri dan miselium jamur, perbedaan produksi senyawa metabolit antifungi (Suryanto et al., 2011) serta perbedaan produksi enzim kitinase dan $\beta$-1,3-glukanase (El-Tarabily et al., 2000; Arora et al., 2007; Suryanto et al., 2011; Suryanto et al., 2012).

Pengamatan Struktur Hifa Abnormal. Pengamatan mikroskopik struktur hifa Colletotrichum sp. setelah diberi perlakuan antagonis dengan tujuh isolat bakteri endofit dilakukan setelah hari ke-7. Aktivitas antagonis dari tujuh isolat bakteri endofit memiliki penghambatan yang hampir sama, menyebabkan hifa Colletotrichum sp. mengalami pertumbuhan yang abnormal dibandingkan dengan hifa Colletotrichum sp. yang tidak diberikan perlakukan bakteri. Abnormalitas hifa ditunjukkan sebagai hifa lisis, putus, bengkok, membengkak dan keriting (Gambar 4.). Pertumbuhan abnormal tersebut memperlihatkan bahwa isolat bakteri endofit mampu merusak hifa sehingga berpotensi sebagai agen pengendali hayati terhadap fungi patogen tanaman.

Abnormalitas hifa sering disebabkan oleh kelompok bakteri kitinolitik. Bersama dengan $\beta-1,3-$ glukanase, kitinase yang dihasilkan oleh bakteri kitinolitik mendegradasi dinding sel jamur. Sebagai respon terhadap keadaan ini hifa jamur terlihat patah, lisis, menggulung, memendek, dan membengkok (Getha \& Vikineswary, 2002; Minaxi \& Saxena, 2010; Suryanto et al., 2012).

\section{Perkembangan Penyakit Bercak Daun Setelah \\ Perlakuan Bakteri Endofit. Pada 30 hari setelah} semai, bercak daun tanaman semangka tidak terlihat pada kontrol (-), sedangkan pada kontrol (+), gejala bercak daun ditemukan di semua daun semangka. Pada kontrol (+), gejala bercak mulai terlihat jelas pada hari ke-7. Di akhir pengamatan 30 hari setelah tanam tanaman terlihat mati.

Perlakuan bakteri endofit BS 01 pada media tanam yang diberi konidia menunjukkan penurunan serangan bercak daun menjadi $24 \%$, sedangkan perlakuan bakteri endofit DS 01 menunjukkan penurunan serangan menjadi $12 \%$ (Gambar 5). Perlakuan bakteri endofit BS 01 dan DS 01 saja pada media yang tidak diberi konidia tidak terlihat adanya serangan bercak daun.

Beberapa penelitian menunjukkan kemampuan bakteri endofit dalam membantu inang mengendalikan jamur patogen yang menyerang melalui induksi sistem

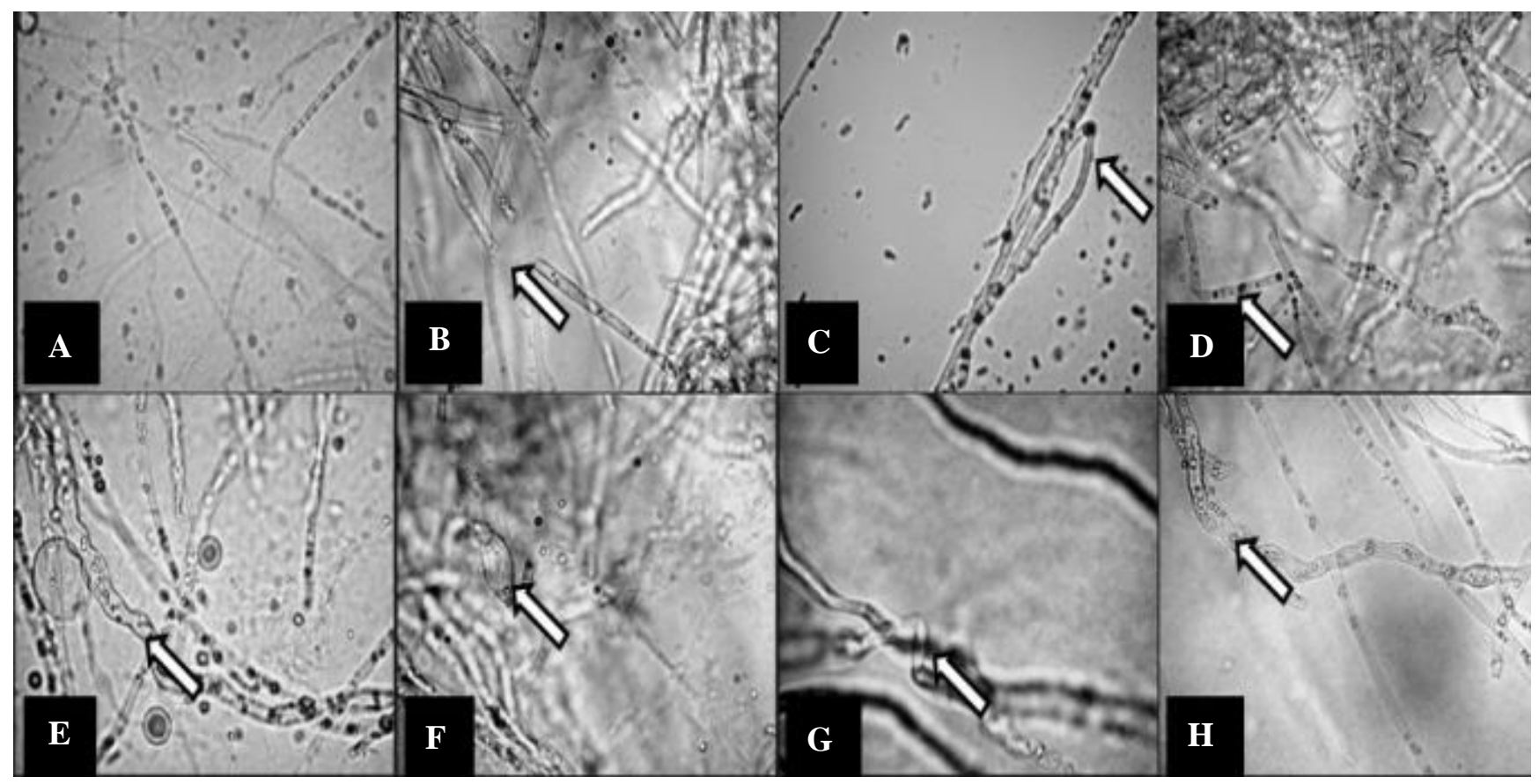

Gambar 4. Hifa abnormal Colletotrichum sp. disebabkan oleh isolat bakteri endofit setelah uji antagonis in vitro: (A) Normal, (B) Putus dan lisis oleh DS 01, (C). Membengkok oleh BS 01, (D) Membengkok oleh AS 01, (E). Keriting oleh AS 02, (F). Membengkak DS 02, (G) Membengkok oleh DS 03, dan (H) Keriting oleh DS 04. 


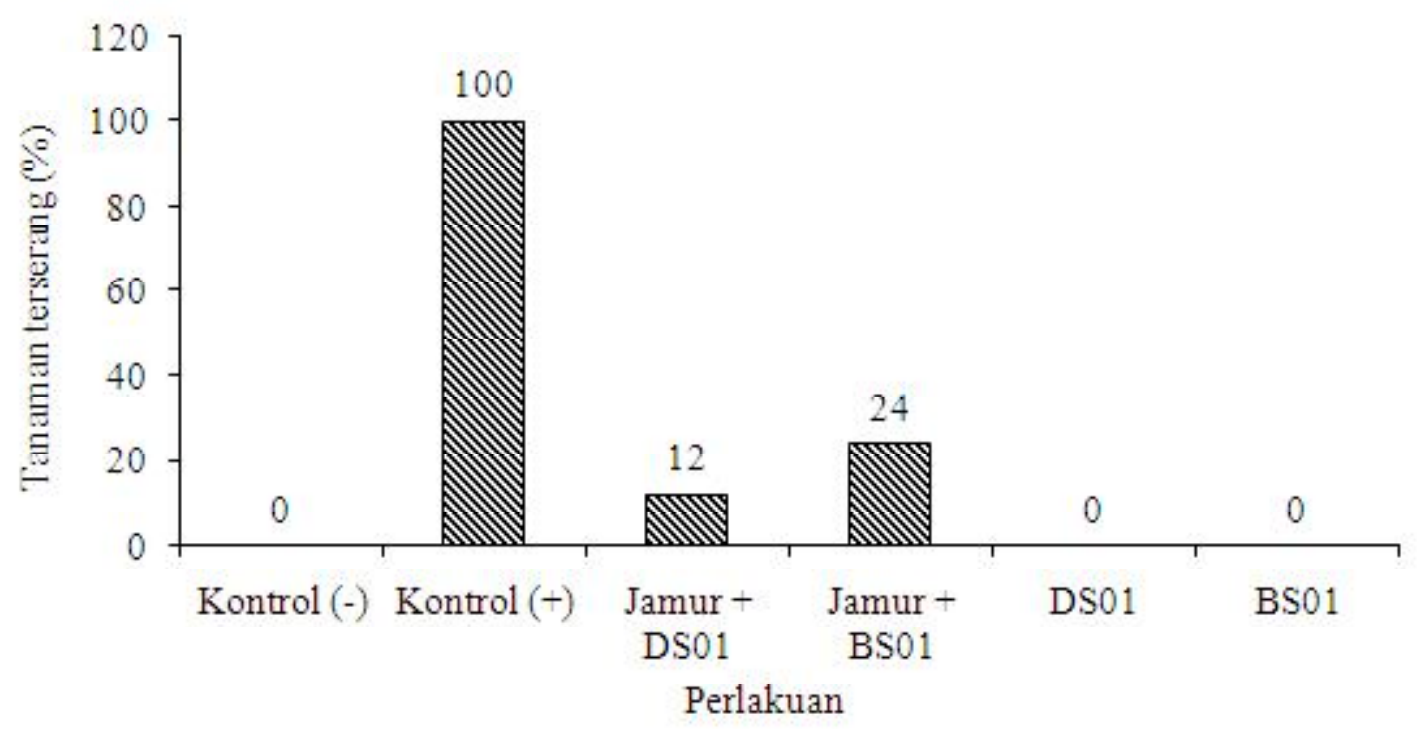

Gambar 5. Persentase bercak daun yang telah diinokulasi Colletotrichum sp. dengan perlakuan bakteri endofit DS 01 dan BS 01

resistensi dan produksi metabolit antijamur (Ramamoorthy et al., 2002; Compant et al., 2005; Attia et al., 2011; Govindappa et al., 2011). Bakteri endofit juga dilaporkan mampu meningkatkan toleransi tanaman terhadap tekanan lingkungan biotik dan memacu pertumbuhan tanaman (Compant et al., 2005; Haggag, 2010; Attia et al., 2011).

Perlakuan pemberian bakteri endofit secara tunggal ternyata menyebabkan cukup banyaknya benih yang tidak tumbuh mencapai $12 \%$ untuk DS 01 dan $44 \%$ untuk BS 01. Hal ini mengindikasikan bahwa meskipun isolat ini mampu menurunkan serangan bercak daun, isolat bakteri endofit ini mungkin jika hidup sendiri dapat merugikan tanaman. Keseimbangan flora normal tanaman boleh jadi terganggu ketika bakteri endofit hidup sendiri dalam tanaman sehingga menyebabkan bakteri endofit tertentu berubah menjadi patogen. Haggag (2010) menyebutkan bahwa mikroba endofitik dapat bersifat simbiotik atau dapat bersifat sedikit patogen. Kemampuan antijamur yang dimiliki oleh isolat-isolat ini digunakan untuk berkompetisi dengan jamur penyebab bercak daun.

Tinggi Tanaman, Jumlah Daun, Berat Kering Benih setelah Perlakuan Bakteri Endofit. Pengukuran tinggi tanaman dilakukan setelah persemaian 30 hari. Hasil pengamatan menunjukkan rata-rata tinggi tanaman yang paling tinggi yaitu pada kontrol (-) dengan rata-rata tinggi tanaman mencapai $103,48 \mathrm{~cm}$, sedangkan rata-rata tinggi tanaman yang terendah terjadi pada kontrol (+) dengan rata-rata tinggi tanaman $2,12 \mathrm{~cm}$ (Gambar 6). Perlakuan dengan penambahan bakteri endofit terhadap tanaman menunjukkan tinggi tanaman yang lebih rendah dari kontrol (-).

Seperti pada tinggi tanaman, hasil pengamatan menunjukkan tidak terdapat perbedaan rata-rata jumlah daun (Gambar 7). Rata-rata jumlah daun terbesar terdapat pada kontrol (-) yaitu sebesar 56,2 dan jumlah daun terendah terdapat pada kontrol (+) yaitu sebesar 1,6. Jumlah daun pada perlakuan bakteri endofit BS 01 dan DS 01 saja lebih rendah dari jumlah daun pada kontrol (-).

Pengukuran berat kering tanaman menunjukkan adanya perbedaan rata-rata berat kering pada masingmasing perlakuan (Gambar 8). Rata-rata berat kering terbesar terdapat pada perlakuan jamur ditambah bakteri DS 01 yaitu sebesar $1,74 \mathrm{~g}$ dan terendah terdapat pada kontrol (+) yaitu sebesar $0,1 \mathrm{~g}$. Berat kering yang tinggi pada perlakuan bakteri endofit dengan jamur mungkin disebabkan bakteri tidak mengambil sumber makanan dari tanaman melainkan menggunakan jamur sebagai sumber makanan. Hasil fotosintat tanaman pada perlakuan ini mungkin lebih digunakan untuk pertahanan fisik sehingga tanaman terlihat lebih kekar tetapi tidak tinggi.

Berat kering tanaman yang berbeda nyata menunjukkan adanya perbedaan akumulasi senyawa organik yag berhasil disintesis tanaman antar perlakuan. Kerusakan pada daun yang disebabkan oleh penyakit bercak daun dapat menyebabkan fotosintat yang dihasilkan tanaman sedikit. Kerusakan bagian lain dari tanaman yang disebabkan oleh jamur dapat memberikan sumbangan terhadap turunnya jumlah nutrisi yang dapat disebar di seluruh bagian tanaman. 


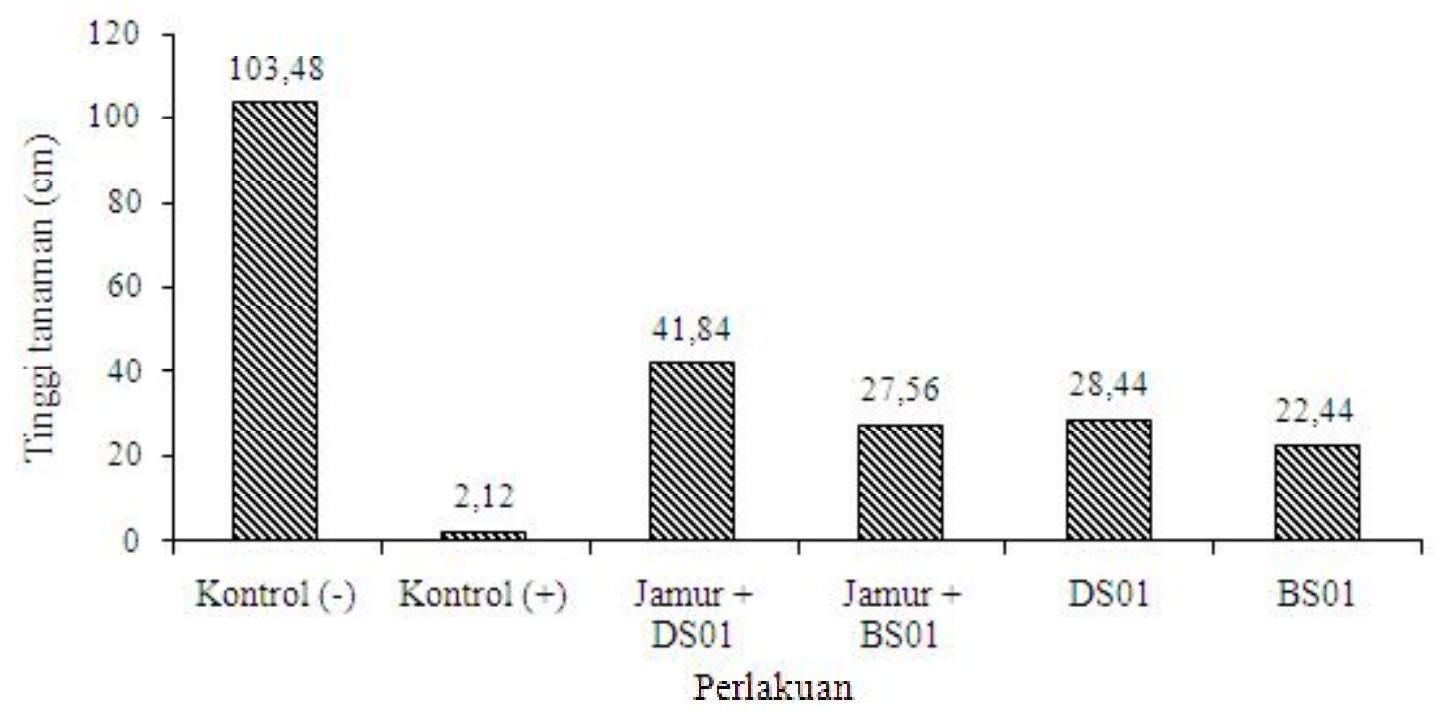

Gambar 6. Perbedaan rata-rata tinggi tanaman semangka yang diberi perlakuan bakteri endofit.

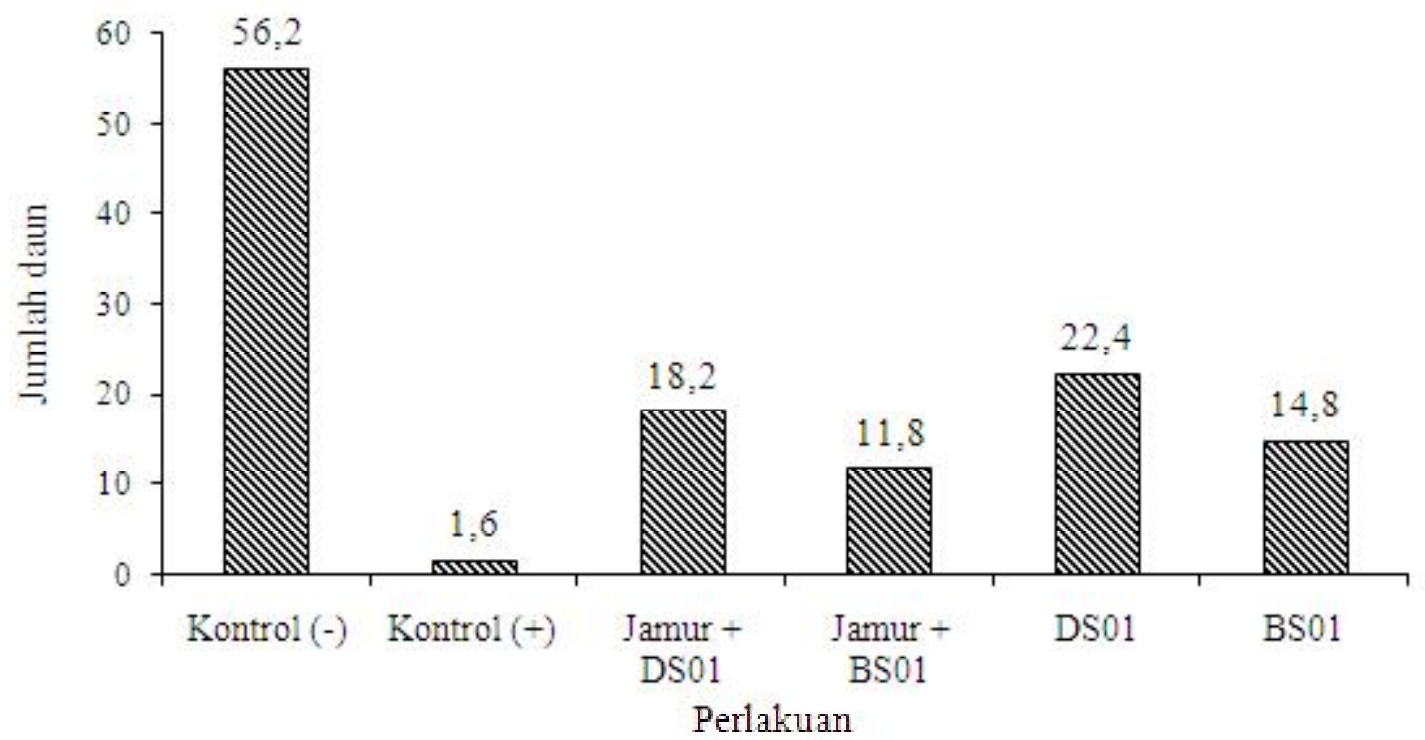

Gambar 7. Perbedaan rata-rata jumlah daun tanaman yang diberi perlakuan bakteri endofit

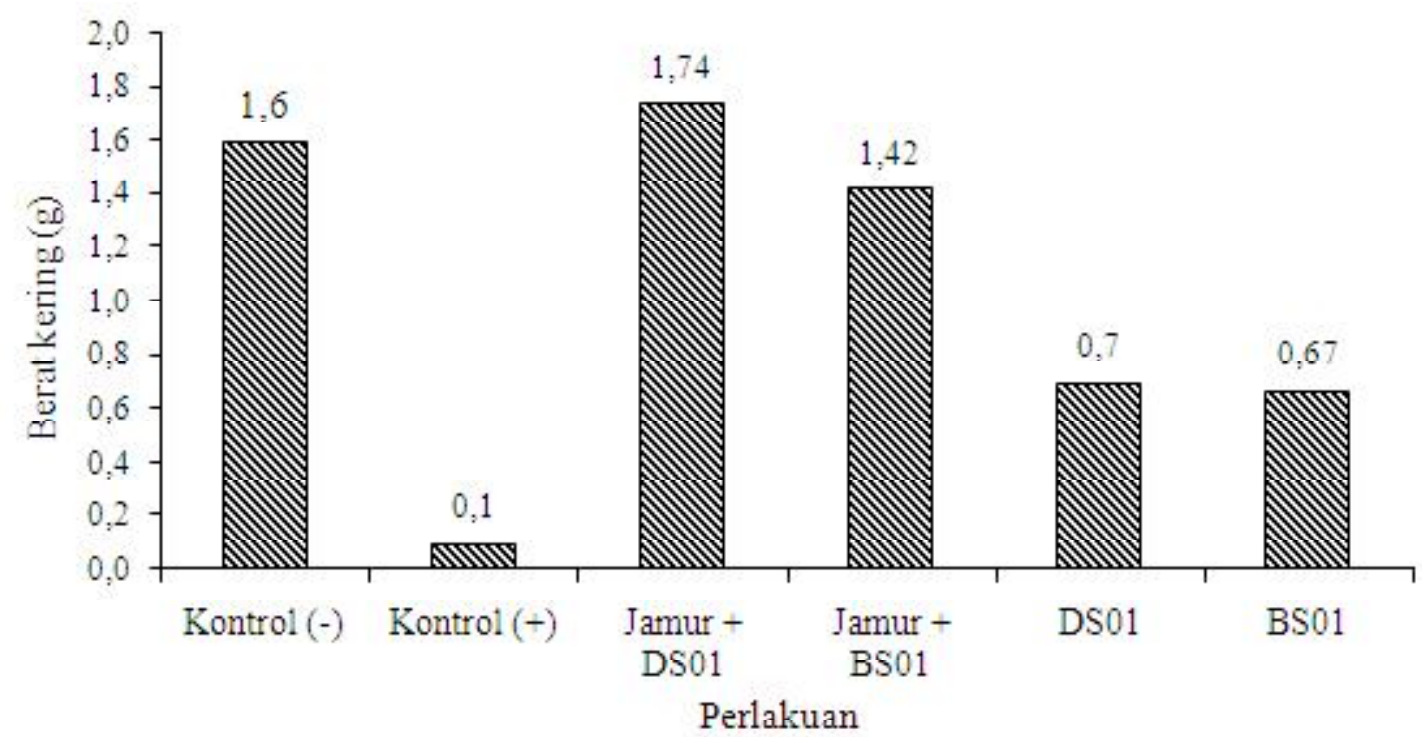

Gambar 8. Perbedaan rata-rata berat kering tanaman yang diberi perlakuan bakteri endofit. 


\section{SIMPULAN}

Tujuh isolat bakteri endofit diisolasi dari tanaan semangka yang sehat. Isolat DS 01 dan BS 01 menunjukkan kemampuan tertinggi dalam menghambat pertumbuhan Colletotrichum sp. secara in vitro. Perlakuan pemberian bakteri endofit DS 01 dan BS 01 dapat menurunkan serangan bercak daun, namun kedua isolat ini yang diberikan secara tunggal menurunkan tinggi tanaman, jumlah daun, dan berat kering dibandingkan kontrol (-), benih yang tidak diberi baik konidia maupun isolat bakteri endofit. Hal ini mengindikasikan bakwa bakteri yang hidup dalam tanaman sehat tidak selamanya berkontribusi terhadap kesehatan tanaman jika tidak hidup bersama-sama dengan bakteri lain. Perlakuan kombinasi beberapa bakteri endofit hasil isolasi dari tanaman semangka perlu dilakukan untuk mengetahui kemampuan menghambat pertumbuhan jamur patogen dan pengaruhnya terhadap performa tanaman.

\section{DAFTAR PUSTAKA}

Alexopoulos CJ \& Mims CW. 1979. Introductory of Mycology. $3^{\text {rd }}$ edition. John Willey and Sons. New York.

Anitha A \& Rabeeth M. 2009. Control of Fusarium wilt of tomato by bioformulation of Streptomyces griseus in green house condition. Afr. J. Basic Appl. Sci. 1(1-2): 9-14.

Arora NK, Min JK, Kang SC, \& Maheshwari DK. 2007. Role of chitinase and [beta]-1,3-glucanase activities produced by a fluorescent pseudomonad and inhibition of Phytophthora capsici and Rhizoctonia solani. Can. J. Microbiol. 53(2): 207-212.

Attia. M, Awad NM, Turky AS, \& Hamed HA. 2011. Induction of defense responses in soybean plants against Macrophomina phaseolina by some strains of plant growth promoting rhizobacteria. J. Appl. Sci. Res. 7(11): 1507-1517.

Compant SB, Duffy NJ, Clement C, \& Barka A. 2005. Use of plant growth promoting bacteria for biocontrol of plant disease: principle, mechanism of action, and future prospect. Appl Environ Microbiol. 71(9): 4951-4959.
El-Tarabily KA, Soliman MH, Nassar AH, Al-Hassani HA, Sivasithamparam K, McKennad F, \& Hardy GEStJ. 2000. Biological control of Sclerotinia minor using a chitinolytic bacterium and actinomycetes. Plant Pathol. 49: 573-583.

Getha K \& Vikineswary S. 2002. Antagonistic effects of Streptomyces violaceusniger strain G10 on Fusarium oxysporum f.sp. cubense race 4: Indirect evidence for the role of antibiosis in the antagonistic process. J. Ind. Microbiol Biotechnol. 28(6): 303-310.

Govindappa M, Ravishankar RV, \& Lokesh S. 2011. Screening of Pseudomonas fluorescens isolates for biological control of Macrophomina phaseolina root-rot of safflower. Afr. J. Agric. Res. 6 (29): 6256-6266.

Haggag WM. 2010. Role of entophytic microorganisms in biocontrol of plant diseases. Life Sci J. 7(2): $57-62$.

Minaxi \& Saxena J. 2010. Characterization of Pseudomonas aeruginosa RM-3 as a potential biocontrol agent. Mycopathologia 170(3): 181193.

Radu S \& Kqueen CY. 2002. Preliminary screening of endophytic fungi from medicinal plants in malaysia for antimicrobial and antitumor activity. Malays. J. Med. Sci. 9(2): 23-33.

Ramamoorthy V, Raguchander T, \& Samiyappan R. 2002. Enhancing resistance of tomato and hot pepper to Pythium diseases by seed treatment with fluorescent pseudomonads. Eur. J. Plant Pathol. 108(8): 429-441.

Suryanto D, Irawati N, \& Munir E. 2011. Isolation and characterization of chitinolytic bacteria and their potential to inhibit plant pathogenic fungi. Microbiol Indones. 5(3): 144-148.

Suryanto D, Wibowo RH, Siregar EBM, \& Munir E. 2012. A possibility of chitinolytic bacteria utilization to control basal stems disease caused by Ganoderma boninense in oil palm seedling. Afri. J. Microbiol Res. 6(9): 2053-2059.

Ziedan EHE. 2006. Manipulating endophytic bacteria for biological control to soil borne diseases of peanut. J Appl Sci Res. 2(8): 497-502. 